\title{
Impact of Live Load on Changes of Backfill Properties of Buried Flexible Steel Railway Structure
}

\section{Adam Wysokowski ${ }^{1}$ (D)}

Accepted: 21 September 2021 /Published online: 1 October 2021

(C) The Author(s) 2021

\begin{abstract}
The article attempts to assess the changes in the properties of the soil backfill on the basis of studies carried out on the soil compaction indicator for a buried flexible steel structure located in a section of the Pan-European railway line. Initial tests on soil compaction showed that the backfilling does not meet the standard for railway structures. On this basis, it was decided to conduct additional studies taking into account the probability of compacting the soil during the operation of the structure. In order to verify any changes, the compaction indicator tests were repeated after 7 months of use under intensive railway load. On this basis, it can to be stated that there is relationship between the impact of a service load and the parameters of a soil backfill over time. As a result of the intense exploitation of a structure, an increase in the soil compaction index even up to $6.0 \%$ (average $2.5 \%$ ) occurs.
\end{abstract}

Keywords Buried flexible steel structures · Culverts · Tests · Railway loads · Backfill properties

\section{Introduction}

The construction of culverts is widely applied in roads, railway lines and airports. The development of technology has significantly changed the methods by which culverts are constructed. Those made of traditional materials are nowadays being increasingly frequently replaced with light buried flexible steel structures, which work together with the soil backfill in transmitting loads (Janusz and Madaj 2007).

Flexible shell structures take advantage of the coaction of a thin shell with the soil backfill; thus, both the fill and shell are the structural elements here, and not, as is the case with rigid structures, merely a backfill (Kang et al. 2008, Liu et al.

Adam Wysokowski

awysokowski@infra-kom.eu

1 Road and Bridges Department, Faculty of Civil Engineering, Architecture and Environmental Engineering, University of Zielona Góra, Prof. Z Szafrana Street No. 1, Building A-8, 65-417 Zielona, Góra, Poland 
2011; Sawamuraa et al. 2018). The shells, which have flexible properties, and the soil material (fill) are therefore the load-bearing structure. Seeing as how the span lengths of currently constructed structures of this type are continuously increasing, backfill is expected to meet increasingly rigorous material and technological requirements (Pettersson et al. 2017).

This results from, among others, numerous carried out studies and analyses which unanimously indicate the strong influence of the applied materials on the widely understood design and performance parameters. The process of backfilling is significant when it comes to the safety of the structure. This process involves the laying of the soil, which distributes a large share of the load impacts-both static as well as dynamic (Rowińska et al. 2004, Machelski 2015). The future operating load bearing capacity of the structure depends on the proper execution of earthworks around it (Thien Mai et al. 2014, Pettersson and Sundquist 2014, Machelski 2008).

The author has actively participated in implementing these types of structures in Poland. He carried out a number of studies on such structures, both laboratoryon a natural scale, as well as in-field (Wysokowski 2017). When implementing these types of structures, the technological regime of their construction is of utmost importance (Yeau et al., 2009; Moore et al. 2017; Maleska and Bęben 2019). This is the reason why errors in construction are often made. Serving as a good example of such errors is the engineering structure described in the present article.

The article describes the results of carried out studies which would make it possible to assess the compaction of the backfill, as well as the displacements of the structure as a result of a live load over the course of time. The culvert, which was designed as a flexible steel structure, is located on the Polish section of the E-30 railway line belonging to the Pan-European Transport Corridor III connecting Germany, Poland and Ukraine with 184 average daily railway traffic (Wysokowski and Górna 2007).

\section{Materials and Methods}

\subsection{General Description of the Structure}

The structure under study was a culvert situated within a station of main railway line allowing the flow of a water course. The load bearing element of the given flexible structure is a shell made from corrugated steel plates of the MULTIPLATE MP150, L16 type, working together with the surrounding soil backfill in distributing the load. The overlapping plates, connected to each other by screws of high durability, create a closed multi-radii cross-section. The foundation of the structure was prepared as a layer of compacted soil, with.

a minimum thickness of $80.0 \mathrm{~cm}$, placed on a geogrid, with an additional $20.0 \mathrm{~cm}$ layer of sub-base. Three railroad tracks with axial spacing of $5.80 \mathrm{~m}$ are found over the structure (Figs. 1 and 2), in relation to which the culvert is situated at an $85^{\circ}$ angle. The clear width of the analysed culvert is $3.22 \mathrm{~m}$, with a height of $2.15 \mathrm{~m}$ and total length of $25.20 \mathrm{~m}$. The corrugation of steel structure was $150 \times 50 \mathrm{~mm}$ with the thickness of $5.0 \mathrm{~mm}$. The class of steel was S235JR. The distance of the rail head 


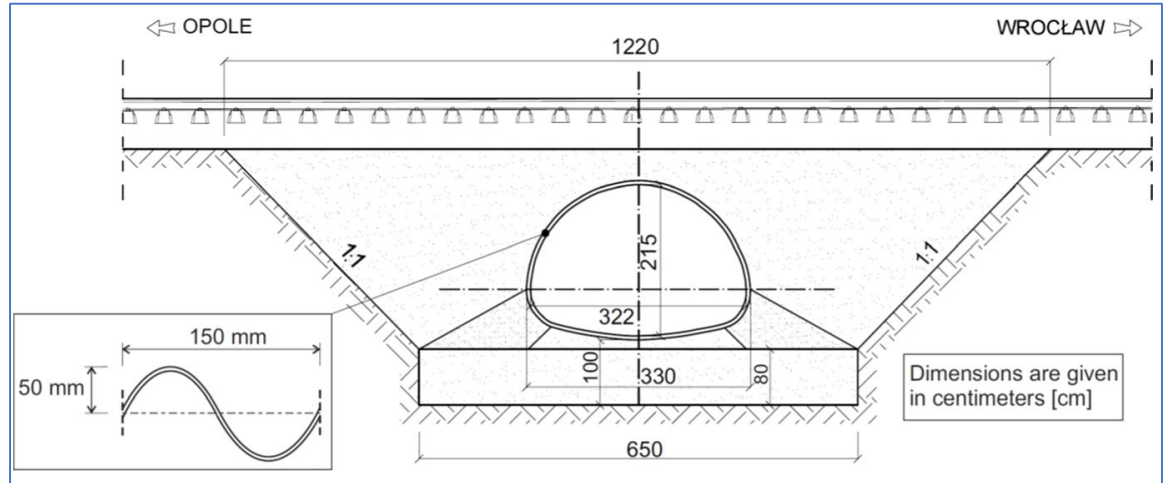

Fig. 1 Transverse section of the culvert structure

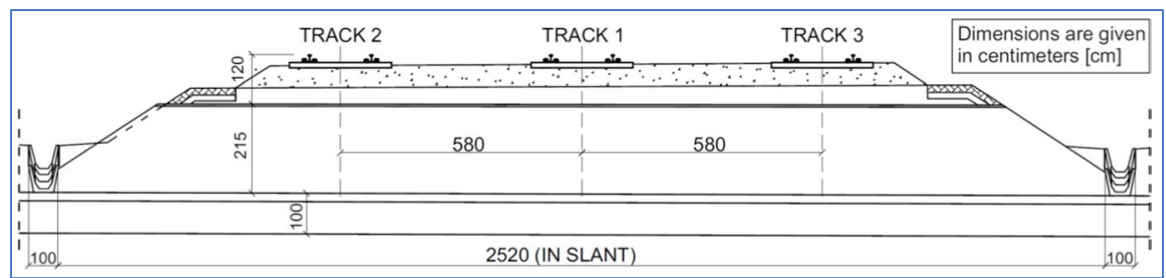

Fig. 2 Longitudinal section of the culvert structure

from the top edge of the structure is $1.20 \mathrm{~m}$. The geometry of the structure and its basic dimensions have been shown in Figs. 1 and 2. Due to its location within the Pan-European corridor, the structure is exposed to.

high intensity of live loads as well as their high frequencies.

The data on the load on the section of the railway line where the structure is located was collected for 5 months by analysing the data obtained from Polish Railway Lines. First of all, the following criteria were taken into account:

- Maximum line speed, $\mathrm{V}_{\max }$

- Line load with freight, $\sum \mathrm{P}$

Table 1 shows the results of traffic measurements for various types of freight trains.

Individual standardized types of trains are shown in Fig. 3.

\subsection{Description of Tests}

The main aim of the testing was to assess the compaction of the soil backfill within a buried flexible steel structure, as well the displacement of the steel shell over time under the influence of railway service load. The displacement of the structures was assessed for the crown and bottom of the structure and horizontal clearance. The 
Table 1 Results of traffic measurements for various types of freight trains

\begin{tabular}{|c|c|c|c|c|c|c|c|c|c|c|c|c|c|c|c|c|c|}
\hline \multirow[t]{3}{*}{$\mathrm{P}[\mathrm{kN} / \mathrm{axle}]$} & \multicolumn{17}{|c|}{ Types of trains and carriages } \\
\hline & \multicolumn{3}{|l|}{1} & \multicolumn{3}{|l|}{2} & \multicolumn{3}{|l|}{3} & \multirow[t]{2}{*}{ Total } & \multicolumn{3}{|l|}{4} & \multicolumn{3}{|l|}{5} & \multirow[t]{2}{*}{ Total } \\
\hline & I & II & III & I & II & III & I & II & III & & I & II & III & I & II & III & \\
\hline 50 & - & - & 4 & 180 & 310 & 8 & - & - & 8 & 510 & - & 4 & & 36 & 4 & - & 44 \\
\hline 100 & 144 & - & - & 180 & 31 & 4 & - & - & 8 & 367 & 36 & 4 & - & 36 & - & 16 & 92 \\
\hline 150 & 72 & - & - & 720 & 1240 & 120 & - & - & 24 & 2176 & - & 12 & - & 36 & - & - & 48 \\
\hline 200 & - & - & - & 108 & 217 & - & 72 & - & - & 397 & 72 & - & - & 252 & 12 & 144 & 480 \\
\hline Total & 16 & - & 4 & 1188 & 1798 & 132 & 72 & - & 40 & 3450 & 108 & 20 & - & 360 & 16 & 160 & 664 \\
\hline
\end{tabular}

measurements were taken along the longitudinal axis of the culvert in transverse sections, established in a $60-\mathrm{cm}$ module. Vertical displacements have been measured using electronic sensors with an accuracy of $\pm 0.001 \mathrm{~mm}$. Horizontal displacements were recorded with mechanical clock sensors with displacement accuracy of $\pm 0.01 \mathrm{~mm}$. The value of soil compaction index $\mathrm{I}_{\mathrm{s}}$ (characterizing the quality of compaction of the backfill) (Szajna 2017) was measured by Cone Penetration Test using the SD10 type probe. All height measurements were carried out using a total station with an accuracy of $\pm 0.5 \mathrm{~mm}$.

Figure 4 presents the locations of characteristic measurement sections selected for analyses, marked from $A$ to $G$ respectively.

Soil compaction tests were carried out at the critical points of the structure affecting the behaviour of the flexible steel structure. The focus was on the both sides of backfill since this zone is the most exposed to impact stresses from the steel shell. The elevation of compaction measurement was made under the layer of structural rail aggregate.

The compaction of the backfill was measured by Cone Penetration Test using the SD10 type probe between railway tracks no. 1 and 2, tracks no. 1 and 3, along the axis of track no. 2 , and in the structure of the railway embankment. Their location has been presented in Figs. 5 and 6.

The studies were carried out in two series: in April and May 2006 and November and December 2006 (7 months later). In the first stage, studies under an experimental static load on tracks no. 2 and 3 were carried out. A type ET22 electric locomotive was assumed as the testing load (the mass in working order was $1177 \mathrm{kN}$ ). This allowed for obtaining a linear load of $75 \mathrm{kN} / \mathrm{m}$ on the level of the edge of the culvert shell, which is approximately $75 \%$ of the value of the normalized standard load (Madaj 2006). The ordinates of the crown as well as bottom of the structure were measured, as well the dimensions of the horizontal clearance, at a distance module of $60.0 \mathrm{~cm}$. The compaction of soil near the analysed structure was also assessed.

The aim of the second series of studies was to establish the values of the dislocations of the structure as well as the compaction of the fill surrounding the culvert, which would make it possible to assess the performance of the flexible steel structure after approximately 1 year of service. For this purpose, the ordinates of the crown and bottom of the structure as well as horizontal clearance were measured 


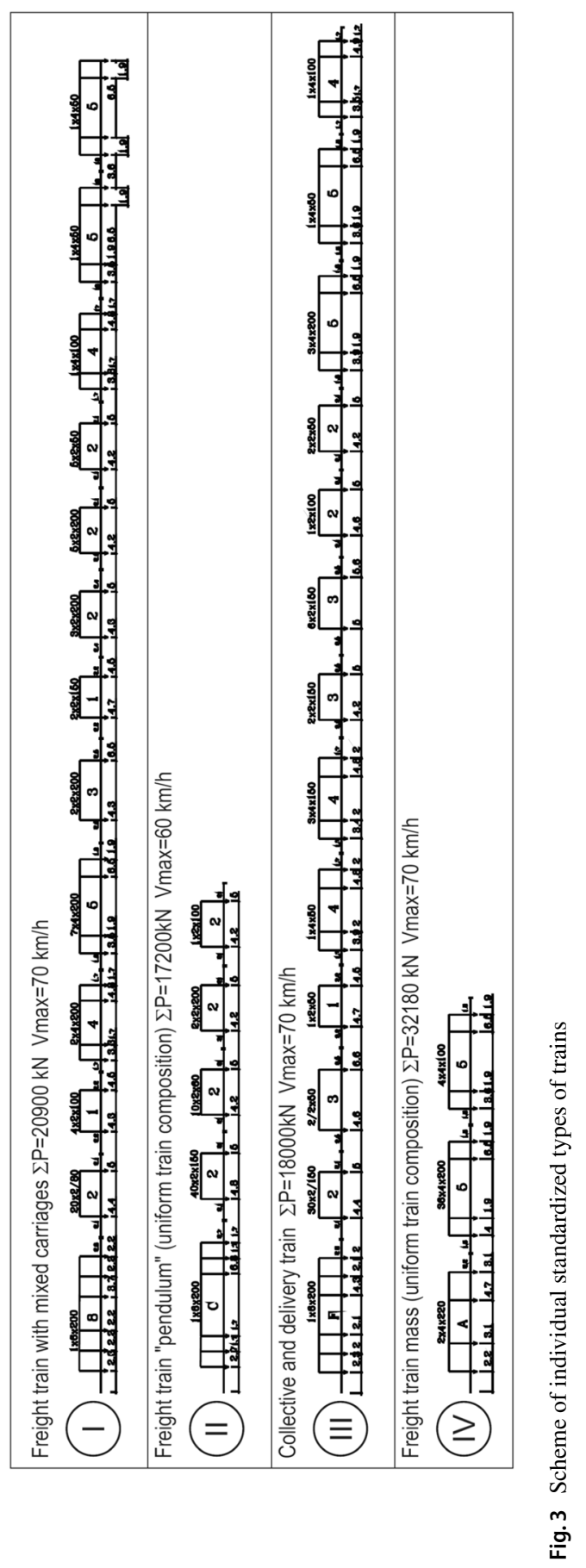




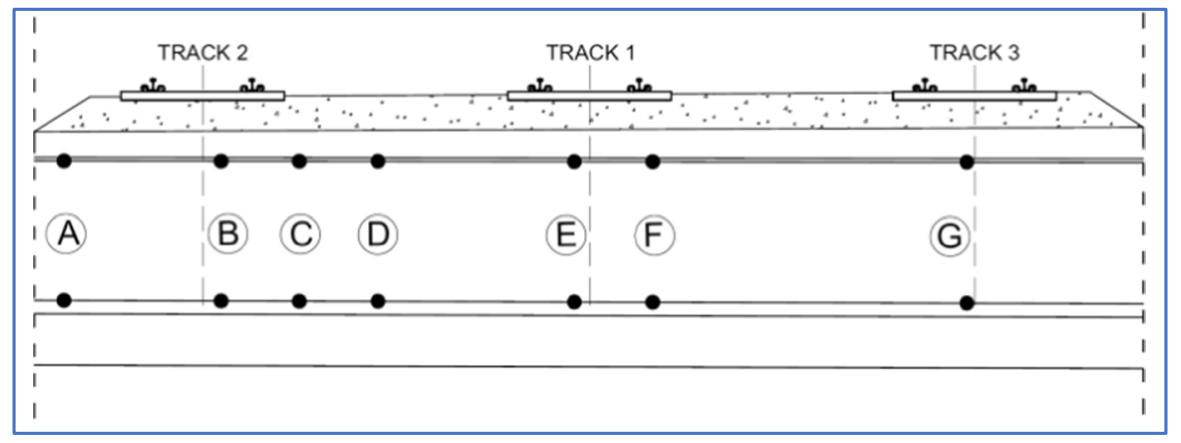

Fig. 4 Scheme of locations of characteristic measurement sections-measuring displacements

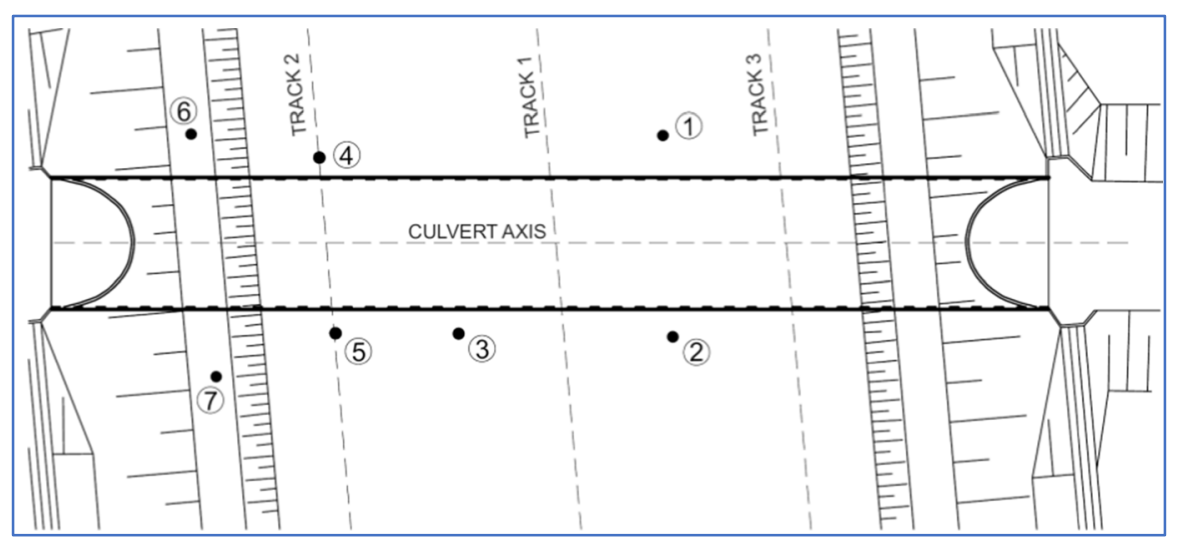

Fig. 5 View from the top of the culvert along with the location of measurement points of backfill compaction.

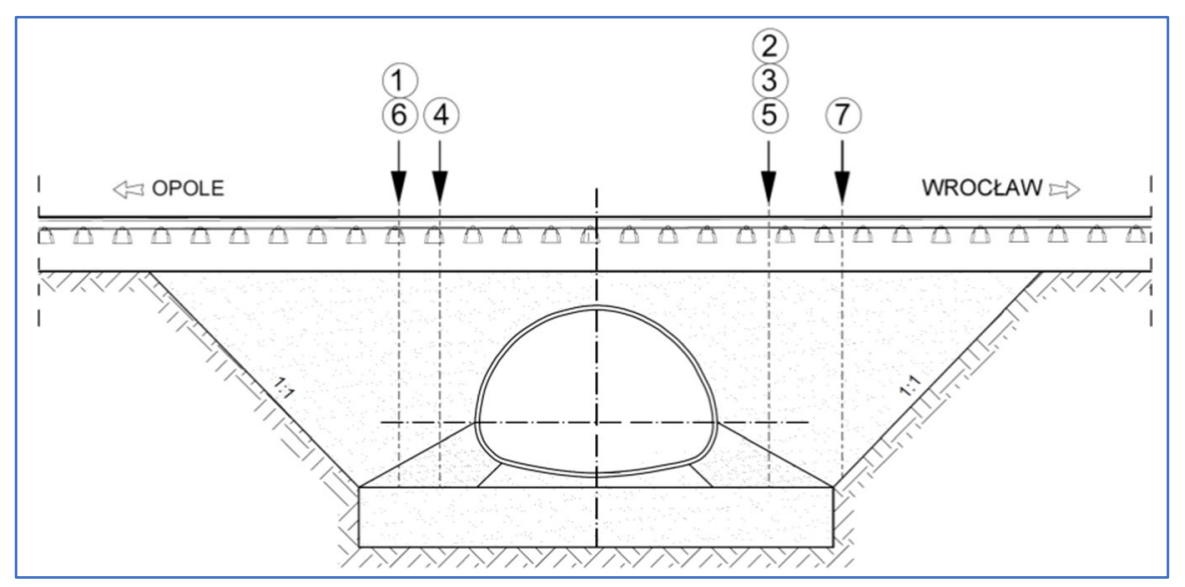

Fig. 6 Transverse section along with location of measurement points of fill compaction 
once again. The soil compaction index " $\mathrm{I}$ " at characteristic measurement points of the soil backfill was also measured (Figs. 5 and 6). The tests have been carried out without additional loading.

\section{Results and Analysis}

For the accurate assessment of the performance of a flexible steel structure over the course of its use, the following tests were carried out:

- Vertical and horizontal displacements of the structure under experimental static load and the backfill compaction index before putting the structure into service

- Vertical and horizontal displacements of the structure along with the backfill compaction index after 7 months of use under service railway load

\subsection{Assessment of Soil Backfill Compaction Index}

According to design guidelines, the backfill of the culvert comprised frost-resistant aggregate, compacted to a compaction index of a minimum of 0.97 in direct proximity of the steel shell, and a minimum of 0.95 at a distance of up to $20.0 \mathrm{~cm}$ from the structure.

Compaction of the soil backfill working together with the analysed structure was assessed twice, i.e., in May and December 2006. In order to obtain reliable study results, the number and distribution of measurement points corresponded to each other in both study series.

Table 2 juxtaposes the results of the studies on compaction index of the culvert backfill in the two study series.

\subsection{Displacement of Crown and Bottom of the Corrugated Plate Structure}

The crown and bottom ordinates along the longitudinal axis of the object at characteristic points were measured twice, i.e. in April and November, which enabled the difference between the vertical displacement values at these points to be determined. The results for the measurement points in characteristic sections of the structure, labelled from A to G in Figs. 4, have been compiled in Table 3.

Table 2 Compilation of the values of the compaction index $I_{s}$ of the culvert backfill in the first and second stage of testing

\begin{tabular}{llllllll}
\hline Test point number & 1 & 2 & 3 & 4 & 5 & 6 & 7 \\
\hline Backfill compaction index I May (M) & 0.93 & 0.92 & 0.97 & 0.92 & 0.94 & 0.93 & 0.94 \\
Backfill compaction index Is December (D) & 0.95 & 0.95 & 0.98 & 0.93 & 0.96 & 0.99 & 0.96 \\
\hline
\end{tabular}


Table 3 Compilation of displacement values of the crown and bottom of the analysed structure in characteristic cross-sections

\begin{tabular}{|c|c|c|c|c|c|c|}
\hline \multirow{2}{*}{$\begin{array}{l}\text { Test } \\
\text { point } \\
\text { number }\end{array}$} & \multicolumn{3}{|l|}{ Crown } & \multicolumn{3}{|l|}{ Bottom } \\
\hline & $\begin{array}{l}\text { Elevation } \\
\text { coordinate } \\
\text { (April) } \\
{[\mathrm{m}]}\end{array}$ & $\begin{array}{l}\text { Elevation } \\
\text { coordinate } \\
\text { (November) } \\
{[\mathrm{m}]}\end{array}$ & $\begin{array}{l}\text { Difference } \\
\text { in elevation } \\
{[\mathrm{m}]}\end{array}$ & $\begin{array}{l}\text { Elevation } \\
\text { coordinate } \\
\text { (April) } \\
{[\mathrm{m}]}\end{array}$ & $\begin{array}{l}\text { Elevation } \\
\text { coordinate } \\
\text { (November) } \\
{[\mathrm{m}]}\end{array}$ & $\begin{array}{l}\text { Difference } \\
\text { in elevation } \\
{[\mathrm{m}]}\end{array}$ \\
\hline A & 122.444 & 122.447 & -0.003 & 120.355 & 120.360 & -0.005 \\
\hline B & 122.399 & 122.402 & -0.003 & 120.276 & 120.280 & -0.004 \\
\hline $\mathrm{C}$ & 122.385 & 122.386 & -0.001 & 120.275 & 120.279 & -0.004 \\
\hline D & 122.379 & 122.374 & 0.005 & 120.261 & 120.265 & -0.004 \\
\hline E & 122.337 & 122.339 & -0.002 & 120.229 & 120.231 & -0.002 \\
\hline F & 122.328 & 122.335 & -0.007 & 120.214 & 120.215 & -0.001 \\
\hline G & 122.288 & 122.286 & 0.002 & 120.144 & 120.148 & -0.004 \\
\hline
\end{tabular}

The graph found in Fig. 7 presents the values of at the analysed measurement points of the crown, whereas the graph contained in Fig. 8 is the ordinates at all measurements points of the bottom of the structure.

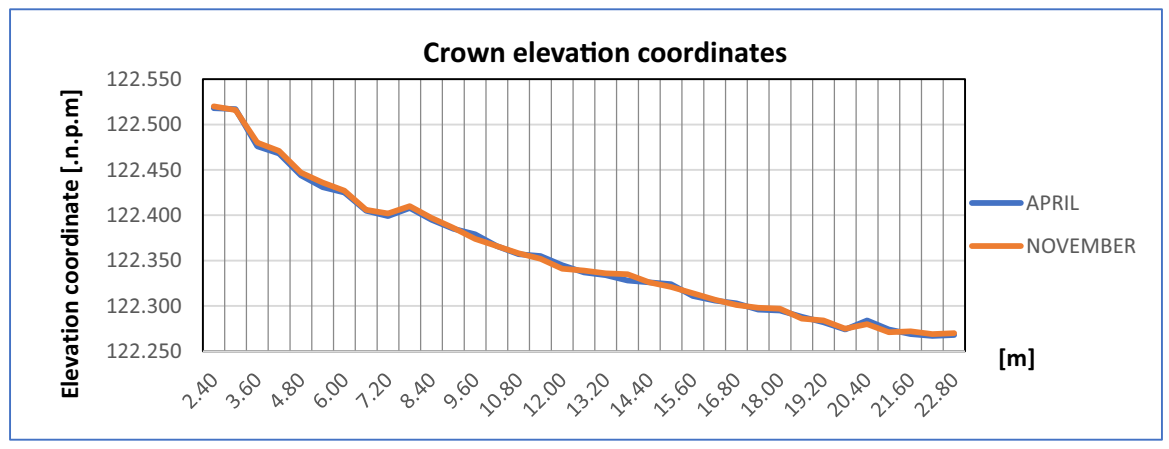

Fig. 7 Graph showing the measured ordinates of the crown structure

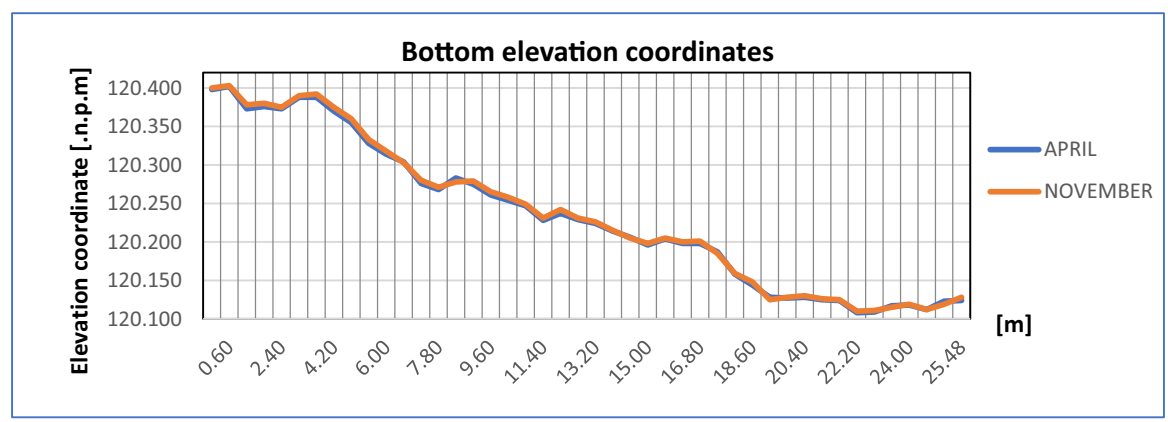

Fig. 8 Graph showing the measured ordinates of the bottom of the structure 


\subsection{Displacement of the Horizontal Clearance of the Structure}

The dimensions of the horizontal clearance of the culvert were measured twice, i.e. in April and November 2006, which allowed for analysing changes in terms of horizontal displacements. Values were read in a section module $60.0 \mathrm{~cm}$ in length along the longitudinal axis of the structure.

The results of the values of the horizontal clearance measured at cross-sections at a modular distance of $60.0 \mathrm{~cm}$ have been compiled in Table 4 .

\subsection{Analysis of Results}

The carried out studies indicated that the soil of the backfill which was used for earthworks around the culvert is fully compactable. The values of the soil compaction index according to measurements carried out in December 2006 as compared to the results from May 2006 and presented in Fig. 9 show progressing soil compaction within the culvert at all tested points. The highest increase in compaction index was observed at point 6 , where the value increased from 0.93 to 0.99 .

As a result of the intense exploitation of structure, an increase in the soil compaction index occurs even up to $6.0 \%$ (average $2.5 \%$ ).

The analysis of vertical displacement measurements of the bottom and crown of the steel shell of the culvert, carried out in the first and second stage of the studies, indicates a slight "uplift" of the steel structure. The vertical displacement of the coating, according to the author, is directly related to the change in the degree of compaction of the side zones of the backfill.

In this case, a higher coefficient of compactness caused a slight "uplift" of the steel structure over time (Fig. 10). At the same time, it should be noted that this phenomenon occurs mainly in the zone of impact of railway loads, which confirms this theory. The registered displacements occur only topically, on short section of the shell structure; endpoints of the culvert did not show significant differences in displacements. This expressly signifies the relationship between soil compaction and changes in geometry of steel flexible structures.

A comparative analysis of the results of measurements in the horizontal clearance of the structure has been presented in the form of a graph in Fig. 11.

Upon analysing the graph contained in Fig. 11, it ought to be stated that, in the majority of the analysed points, the value of the displacement of the horizontal clearance of the culvert obtained in the second series of the studies is significantly smaller. This signifies that geometric stabilization of the steel structural shell takes pace over time, i.e. a small upheaval of the crown of the steel shell. The geometric shape of the cross-section of the structure is therefore attempting to the reach the initial- design geometry of the shell.

When analysing the obtained comparative results of the culvert displacements, especially the bottom and crown of structure, it should be stated that this is the result of soil compaction in the side areas of the structure. In these areas, the soil is compacted, so there is horizontal pressure on the buried steel structure on both 
Table 4 Compilation of results of the measured horizontal clearance of the analysed structure
Distance [m] Horizontal clear- Horizontal clear- Disparity [m] ance Apr. [m] ance Nov. [m]

\begin{tabular}{|c|c|c|c|}
\hline 25.48 & 3.220 & 3.221 & -0.001 \\
\hline 25.20 & 3.215 & 3.210 & 0.005 \\
\hline 24.60 & 3.200 & 3.195 & 0.005 \\
\hline 24.00 & 3.200 & 3.196 & 0.004 \\
\hline 23.40 & 3.202 & 3.197 & 0.005 \\
\hline 22.80 & 3.202 & 3.198 & 0.004 \\
\hline 22.20 & 3.187 & 3.186 & 0.001 \\
\hline 21.60 & 3.190 & 3.188 & 0.002 \\
\hline 21.00 & 3.197 & 3.193 & 0.004 \\
\hline 20.40 & 3.187 & 3.187 & 0.000 \\
\hline 19.80 & 3.194 & 3.189 & 0.005 \\
\hline 19.20 & 3.190 & 3.194 & -0.004 \\
\hline 18.60 & 3.196 & 3.198 & -0.002 \\
\hline 18.00 & 3.198 & 3.203 & -0.005 \\
\hline 17.40 & 3.215 & 3.220 & -0.005 \\
\hline 16.80 & 3.222 & 3.219 & 0003 \\
\hline 16.20 & 3.220 & 3.216 & 0.004 \\
\hline 15.60 & 3.208 & 3.212 & -0004 \\
\hline 15.00 & 3.212 & 3.213 & -0.001 \\
\hline 14.40 & 3.220 & 3.215 & 0.005 \\
\hline 13.80 & 3.210 & 3.215 & -0.005 \\
\hline 13.20 & 3.214 & 3.218 & -0.004 \\
\hline 12.60 & 3.220 & 3.215 & 0.005 \\
\hline 12.00 & 3.205 & 3.208 & -0.003 \\
\hline 11.40 & 3.210 & 3.211 & -0.001 \\
\hline 10.80 & 3.215 & 3.211 & 0.004 \\
\hline 10.20 & 3.206 & 3.209 & -0.003 \\
\hline 9.60 & 3.210 & 3.209 & 0.001 \\
\hline 9.00 & 3.218 & 3.215 & 0.003 \\
\hline 8.40 & 3.205 & 3.208 & -0.003 \\
\hline 7.80 & 3.210 & 3.210 & 0.000 \\
\hline 7.20 & 3.215 & 3.211 & 0.004 \\
\hline 6.60 & 3.215 & 3.216 & -0.001 \\
\hline 6.00 & 3.213 & 3.212 & 0.001 \\
\hline 5.40 & 3.223 & 3.218 & 0.005 \\
\hline 4.80 & 3.225 & 3.227 & -0.002 \\
\hline 4.20 & 3.225 & 3.225 & 0.000 \\
\hline 3.60 & 3.235 & 3.231 & 0.004 \\
\hline 3.00 & 3.235 & 3.230 & 0.005 \\
\hline 2.40 & 3.205 & 3.210 & -0.005 \\
\hline 1.80 & 3.203 & 3.200 & 0.003 \\
\hline 1.20 & 3.193 & 3.189 & 0.004 \\
\hline
\end{tabular}


Table 4 (continued)

\begin{tabular}{llll}
\hline Distance [m] & $\begin{array}{l}\text { Horizontal clear- } \\
\text { ance Apr. [m] }\end{array}$ & $\begin{array}{l}\text { Horizontal clear- } \\
\text { ance Nov. [m] }\end{array}$ & Disparity [m] \\
\hline 0.60 & 3.198 & 3.193 & 0.005 \\
0.00 & 3.214 & 3.212 & 0.002 \\
\hline
\end{tabular}

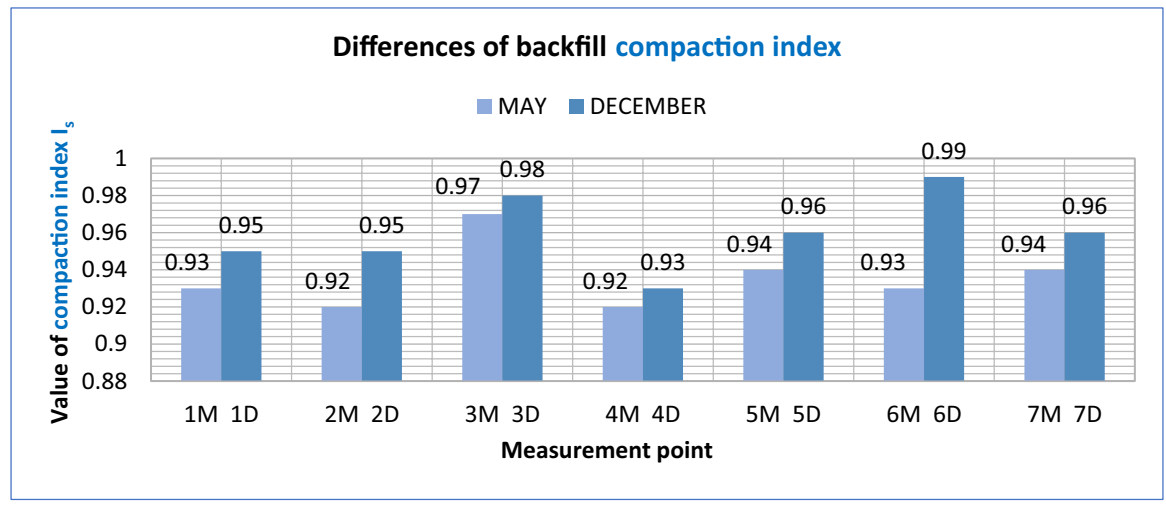

Fig. 9 Graph presenting the compaction index at given measurement points noted in May (M) and December (D).

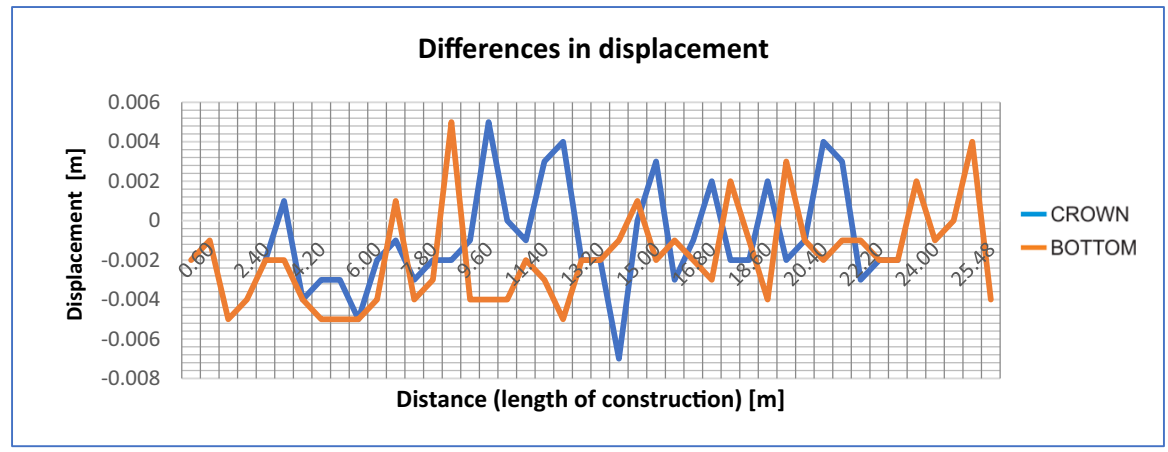

Fig. 10 Graph showing the measured differences in displacement values of the bottom as well as crown of the steel shell structure

sides. This is in line with the mechanics of buried flexible structures. At the same time, it should be stated that the difference in displacements is relatively small and the greatest differences occur directly under load (under the railroad tracks). This confirms the assumption that in the time of exploitation of culvert, the soil compacts under the influence of the live load-especially the dynamic interactions. The observed slight elevation of the crown of the steel structure does not affect the geometry of the railway track and thus the operating conditions of the railway line. 


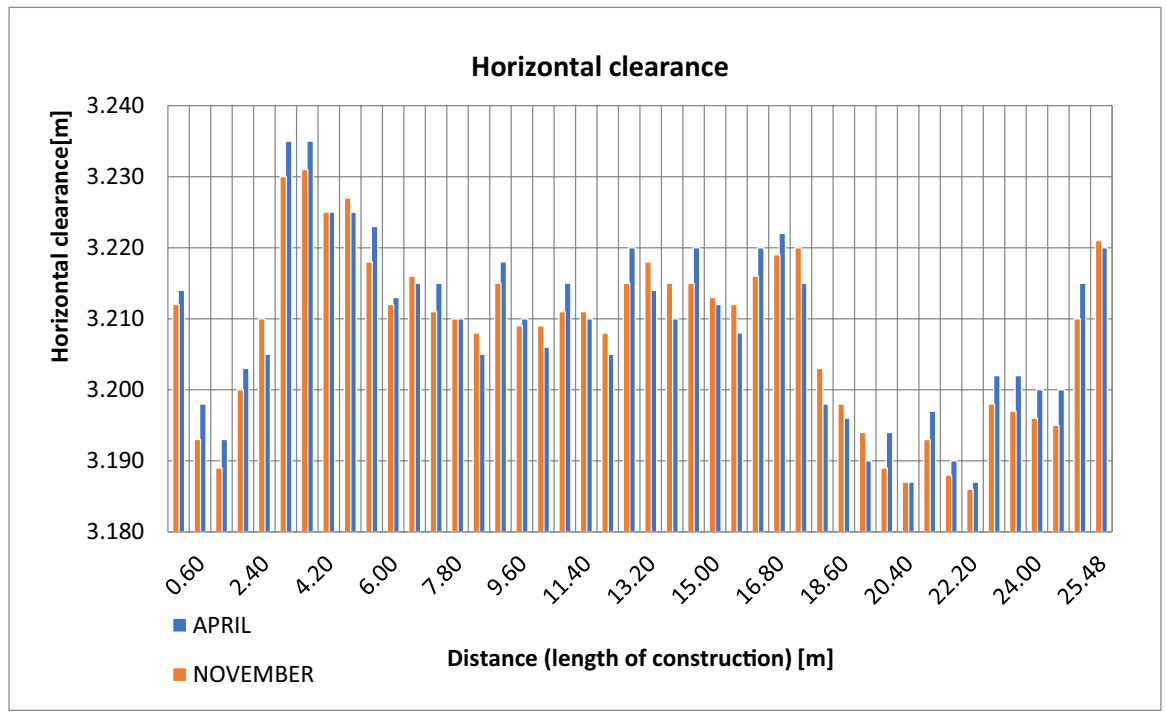

Fig. 11 Graph presenting a comparison of the obtained dimensions of the horizontal clearance of the culvert measured in April and November

\subsection{The Concept of Stabilizing the Structure}

Based on the analysis of the obtained study results, it ought to be stated that, following a short time of the culvert being in use (7 months) - subjecting the structure to service loads - the compaction index of the soil backfill reached design values. Nevertheless, taking into account the length of the culvert (the structure is located beneath three railway tracks) as well as the non-symmetrical nature of service loads, the author devised a concept for strengthening and stabilizing the structure of the backfill in direct proximity of the shell structure (there was a risk that the end zones of the embankment would be exposed to deformation).

This concept involved applying additional special massive structures aimed to stabilize the backfill at the headwalls of the culvert. For this purpose, monolithic retaining blocks in the form of reinforced concrete slabs with a large slope and situated on the side surface of the backfill embankments were developed (Sanaeiha et al. 2017). The two-way retaining structure, in this case, was formed by abutments preventing the loosening of the backfill in a longitudinal direction (transversely to the railway axis) as a result of the impact of dynamic railway service loads.

The assumptions of the prepared concept were then used when creating the reinforcement of the culvert massive headwalls using stabilized soil as well as concrete elements in the form of concrete blocks (Fig. 12a).

In October 2018, an overview of the technical condition of the structure was made.

The main purpose of the inspection was a detailed review of the object in terms of technical condition of the main structural elements. In particular, the corrugated steel shell structure and the joints between the plate sheets have been focused. 

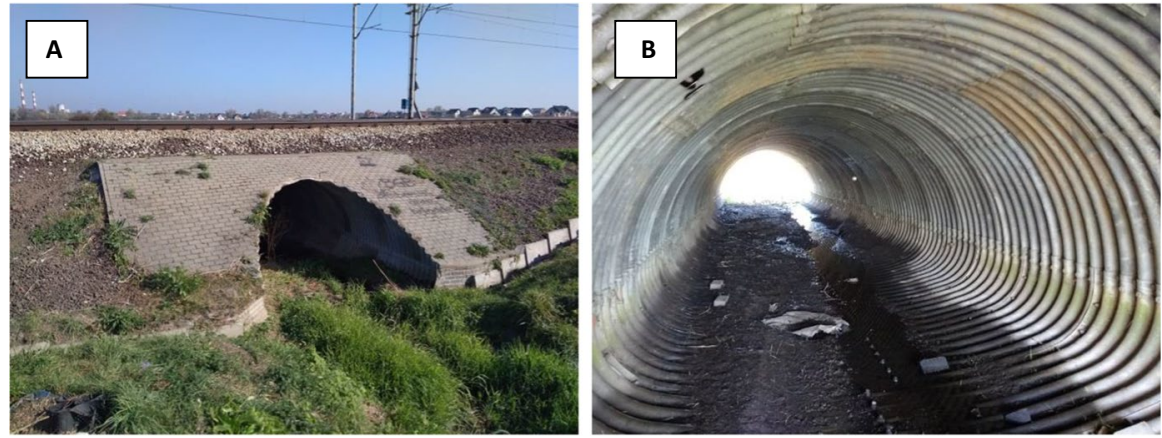

Fig. 12 View of structure of culvert following 12 years of use (October 2018): a general view of the structure, visible massive reinforcement of the wall; $\mathbf{b}$ inside view of steel shell from the corrugated steel plate, lack of visible geometrical imperfections of the shell

Expertise works indicated that the technical condition of the bearing structure of the culvert does not raise any objections in terms of its normal operation (during the inspection, only the unsatisfactory aesthetics of the object were found).

The object has been in normal service under heavy railway loads for 12 years. The result of the inspections proves the full usefulness of the culvert structure.

\section{Conclusions}

In the case of flexible structures which are the subject of the article, the proper compaction of the soil is a very significant parameter influencing the load-carrying ability and stability of the constructed buried flexible steel structure. This is of high importance at the stage of constructing structures of this type, as the proper consolidation of the soil facilitates full cooperation of the flexible shell structure in distributing service loads (Moore and Taleb 1999; Sobótka 2014; Regier et al. 2016; Kraus et al. 2011).

On the basis of the presented study results, it ought to be stated that relationships exist between the impact of a service load and the parameters of a soil backfill over time.

As a result of the intense use of a construction characterized by a buried flexible steel structure-in this case a railway culvert-an increase in the soil compaction index occurs (up to $6.0 \%$ ). Serving to confirm this is the comparative analysis of the results of soil compaction, which showed an increasing tendency in all of the analysed points (both in the axis of the railway tracks and the outside of them).

This process can most likely be explained by changes taking place in the structure of the backfill material, in which, over the course of a series of variable loads, the process of intermolecular consolidation occurs.

Moreover, the carried out studies of displacements as well as the geometry of the shell in the horizontal plane over time did not indicate significant settling of the structure as well as changes in the value of the horizontal clearance. The registered 
vertical displacements (a slight "uplift" of steel structure) occur only topically—on short section-mostly in the zone of impact of railway loads. This expressly signifies the relationship between soil compaction and changes in geometry of steel flexible structures. At the same time, the analysed flexible steel structure became geometrically "stabilized" by the consolidation of the soil backfill. Therefore, it ought to be stated that full cooperation of the shell and backfill were obtained as a result of the effects of service loads. This reinforced structure has been in operation for over 12 years and, in terms of construction, is fully functional.

Serving as proof of the above thesis can be the photographs of the structure described in the article following 12 years of use (2018), which do not reveal any settling or geometrical imperfections (Fig. 12).

Errors in construction pertaining to the backfill have been confirmed by the results of the carried out studies. The repair procedure of the structure and results of studies obtained over the course of use indicate the proper performance of the structure and, at the same time, elimination of the occurring errors. The long-standing use of this structure under intensive railway traffic confirms that the means presented in the article can be used in other similar practical cases.

Often, however, the practical approach to the backfill is disproportionate to the technological requirement for the corrugated buried flexible structures. Despite technological progress and access to the latest achievements in the field of calculating these structures, the backfill still plays a secondary role at the construction stage of these structures.

The conducted tests showed an improvement in the strength parameters of the soil (its compaction) during operation, without the need for densification or the use of reinforcing geotextiles. This would involve the need to limit rail traffic.

The carried out studies ought to be treated as exploratory in the understanding of the described phenomenon. In these analyses, it would be important to compare the amounts and number of cyclical loads to the obtained results of the durability properties of the soil backfill. This gives a reason to continue these kinds of studies upon erecting such types of structures in order to expressly determine the relationships between service loads and the load-bearing capacity and durability of flexible steel structures (Asp and Laaksonen 2017). The author believes that such analyses would enable the determination of an additional coefficient determining the assessment of the load capacity during the operation time of these types of structures.

Acknowledgements Research work was carried out at the Polish Road and Bridge Research Institute as part of the implementation program of buried steel flexible structures in Polish road and railway infrastructure. The author would like to thank the Road and Bridge Research Institute for the possibility of conducting this research and the Polish Railway Administration for cooperation considering the inconvenience of temporarily railway traffic changes.

Author Contribution The author contributed to the study conception and design. Material preparation, data collection and analysis were performed Prof. Adam Wysokowski. The manuscript was written and also the final version was approved by Prof. Adam Wysokowski.

Availability of Data and Material All data used during the study appear in the submitted article.

Code Availability Not applicable. 


\section{Declarations}

Conflict of Interest The author declares no competing interests.

Open Access This article is licensed under a Creative Commons Attribution 4.0 International License, which permits use, sharing, adaptation, distribution and reproduction in any medium or format, as long as you give appropriate credit to the original author(s) and the source, provide a link to the Creative Commons licence, and indicate if changes were made. The images or other third party material in this article are included in the article's Creative Commons licence, unless indicated otherwise in a credit line to the material. If material is not included in the article's Creative Commons licence and your intended use is not permitted by statutory regulation or exceeds the permitted use, you will need to obtain permission directly from the copyright holder. To view a copy of this licence, visit http://creativecommons.org/licen ses/by/4.0/.

\section{References}

Asp, O., Laaksonen, A.: Instrumentation and monitoring of large-span culvert built under a railway in Finland. Archives of Institute of Civil Engineering 23, 53-60 (2017). https://doi.org/10.21008/j. 1897-4007.2017.23.05

Janusz L., Madaj A. (2007). Buried flexible steel structures. Designing and execution, Transport and Communication Publishers, Warsaw, Poland.

Kang, J., Parker, F., Yoo, C.H.: Soil-structure interaction for deeply buried corrugated steel pipes Part I: Embankment installation, Engineering Structures, Vol. 30, Issue 2, February 2008, pp. 384-392 (2008). https://doi.org/10.1016/j.engstruct.2007.04.014

Kraus, E., Fernando, E.G., Li, Y.E., Oh, J.H., Koncz, N.A., Quiroga, C.A. Evaluating the impact of overweight load routing on buried utility facilities. Texas Transportation Institute. Report No. FHWA/ TX-11/0-6394-1 (2011). http://tti.tamu.edu/documents/0-6394-1.pdf.

Liu, B., Zhang, M., Li, P., Feng, Z.: Effect of parameters on soil-structure interaction of a buried corrugated steel arch bridge. Open Civ Eng J 5, 154-162 (2011). https://doi.org/10.2174/1874149501 105010154

Machelski, C.: Calculations for buried shell bridges. Wrocław Publishing Series on Bridge Engineering. Lower Silesia Educational Publishing. Wrocław, Poland (2008)

Machelski, C.: Stiffness of railway soil-steel structures. Studia Geotechnica et Mechanica, Vol. 37, No. 4 (2015). https://doi.org/10.1515/sgem-2015-0042

Madaj, A.: The test results under a static load of the culvert in $\mathrm{km} 170.16$ at the Otawa section - Wroctaw Brochów at St Catherine station. Poznan University of Technology, Faculty of Civil and Environmental Engineering. Poland (2006).

Maleska, T., Bęben, D.: Numerical analysis of a soil-steel bridge during backfilling using various shell models. Engineering Structures. Vol. 196, 1 (2019). https://doi.org/10.1016/j.engstruct.2019.109358

Moore, J.D., Regier, C., Hoult, N.A.: Surface load testing of new circular and elliptical metal culverts at shallow cover. Archives of Institute of Civil Engineering 23, 219-227 (2017). https://doi.org/10. 21008/j.1897-4007.2017.23.20

Moore, I.D., Taleb, B. (1999). Metal culvert response to live loading - performance of three-dimensional analysis. Transportation Research Record No. 1656, Underground and Other Structural Design Issues. National Research Council, Washington, pp. 37-44. https://doi.org/10.3141/1656-05

Pettersson L., Sundquist H. (2014). Design of soil steel composite bridges. TRITA-BKN. Report 112, 5th Edition. ISSN 1103 - 4289.

Pettersson L. Wadi A., Williams K. (2017). Structural design of flexible culverts development trends. Archives of Institute of Civil Engineering. No. 23, 2017. https://doi.org/10.21008/j.1897-4007. 2017.23.22.

Regier, C., Hoult, N.A., Moore, I.D. (2016). Laboratory study on the behavior of a horizontal-ellipse culvert during service and ultimate load testing, Journal of Bridge Engineering, ASCE, pp. 04016131-1 to 14. https://doi.org/10.1061/(ASCE)BE.1943-5592.0001016. 
Rowińska W., Wysokowski A., Pryga A. (2004). Design and technology recommendations for flexible road engineering constructions from corrugated steel plates. General Directorate of National Roads and Motorways, Road and Bridge Research Institute. Żmigród, Poland. https://www.gddkia.gov.pl/ userfiles/articles/z/zarzdzenia_generalnego_2004/Zalecenia_do_zarzdzenia_29.pdf

Sanaeiha A., Rahimian M., Sadegh Marefat M. (2017). Field test of a large-span soil-steel bridge stiffened by concrete rings during backfilling. J Bridge Eng. Volume 22. Issue 10. https://doi.org/10. 1061/(ASCE)BE.1943-5592.0001102

Sawamuraa, Y. Ishiharab, H., Otanic, Y., Kishidad, K., Kimuraa, M.: Deformation behavior and acting earth pressure of three-hinge precast arch culvert in construction process. Underground Space (2018). https://doi.org/10.1016/j.undsp.2018.09.005

Sobótka, M.: Numerical simulation of hysteretic live load effect in a soil-steel bridge. Studia Geotechnica et Mechanica, Vol.36, No. 1, (2014). https://doi.org/10.2478/sgem-2014-0012.

Szajna W. St. (2017). The influence of acceleration on the efficiency of sand compaction tests conducted on a vibrating table. CEER 2017; 24 (1): 169-183. https://doi.org/10.1515/ceer-2017-0012

Thien Mai V., Hoult N.A., Moore I.D. (2014). Effect of deterioration on the performance of corrugated steel culverts. Journal of Geotechnical and Geoenvironmental Engineering Vol. 140, Issue 2 (2014). https://doi.org/10.1061/(ASCE)GT.1943-5606.0001021

Wysokowski A. (2017). Durability of flexible steel corrugated shell structures - theory and practice. III European Conference on "Buried Flexible Steel Structures". Rydzyna, Poland. https://doi.org/10. 21008/j.1897-4007.2017.23.32

Wysokowski A. Górna J. (2007). Technical opinion about strengthen the railway culvert at km 170.168 on the Oława - Wrocław Brochów section -St Catherine station. Road and Bridge Research Institute, Żmigród - Węglewo.

Yeau K. Y., Sezen H., Fox P. (2009). Load performance of in situ corrugated steel highway culverts. Journal of Performance of Constructed Facilities Vol. 23, Issue 1. https://doi.org/10.1061/(ASCE) 0887-3828(2009)23:1(32)

Publisher's Note Springer Nature remains neutral with regard to jurisdictional claims in published maps and institutional affiliations. 